\title{
The Batik Kompeni Ornament Variety As An Acculturation Result In The Development Of Batik Decorative Motifs In Cirebon Coastal
}

\author{
Nuning Yanti Damayanti ${ }^{1 *}$, Ariesa Pandanwangi ${ }^{2}$, Belinda Sukapura Dewi ${ }^{3}$, \\ Arleti Mochtar Apin ${ }^{4}$
}

\author{
${ }^{1}$ Faculty of Art and Design, Institut Teknologi Bandung \\ ${ }^{2}$ Universitas Kristen Maranatha \\ ${ }^{3}$ Universitas Kristen Maranatha \\ ${ }^{4}$ Institut Teknologi Harapan Bangsa \\ *Corresponding Email: nydamayanti10@gmail.com
}

\begin{abstract}
Batik Kompeni is one of batik style with a typical Cirebon ornaments variety, including the popular coastal batik area. It is estimated that the Batik Kompeni emerged in the 1800-1900s period during the Dutch Colonialism in Cirebon. The ornamental variety of the Batik Kompeni shows the results from the aesthetical acculturation process between local and European ornaments during the development of batik ornaments in Cirebon. The Dutch businessmen that interacted socially with batik artists and craftsmen in Cirebon in the early 19th century is thought to have contributed on developing Batik Kompeni production in Cirebon, that later distributed in the north coast of Java Island. In the future, the decorative ornaments of Batik Kompeni have inspired many modern batik artists, craftsmen, and entrepreneurs until now and have become one of the most popular batik patterns. This paper is the result of research tracing the aesthetic acculturation of the Batik Kompeni ornaments. The method of qualitative analysis in this research is through documentation of the Company's Batik ornaments and literature studies, as well as field surveys and interviews with artists, batik craftsmen and batik collectors. The results showed that the openness of the batik craftsmen and the creation of batik ornaments in the Cirebon coast were dynamic, which has enabled the acculturation to occur. Batik Kompeni continues to grow until now into various ornaments which eventually became a typical Cirebon ornament.
\end{abstract}

\section{Keywords: Acculturation, Batik Kompeni, Cirebon, Ornamental Batik Motif.}

\section{INTRODUCTION}

Batik received recognition as an intangible Heritage by the United Nations for UNESCO, on October 2, 2009. Batik, is created using a technique of making ornaments on traditional Indonesian fabrics that has been done for hundreds of years old by using melted wax which are drawn on the fabric in form of object's ornament. Colour barrier between colours on fabric ornaments. The technique of hand-drawn batik is still used in dyeing cloths in Indonesia, and even until now there are many artists that have studied this technique in various countries as an alternative for artistic expression. One of the unique batik ornaments is the Batik Kompeni, which has begun to develop during the Dutch colonial period in Indonesia on the early $19^{\text {th }}$ century. During that period, Dutch entrepreneurs took part in developing the Batik industry, especially in the Cirebon Batik centre [1]. Batik production is also increasing well, especially in the creation of new patterns and ornaments that reflect the mixing of visual elements or acculturation between Eastern and Western culture (Indonesia and Europe). Batik Kompeni continues to develop into new variants of batik ornaments, and according to the results of the data study, it is most likely that the Batik Kompeni was first produced in the Cirebon Batik industrial centre, in which it is a result of cultural acculturation and influence of Cirebon Traditional Batik artists in creating new Batik Kompeni ornaments. Batik Kompeni also has the local content that shape the identity to Cirebon's Batik. 


\section{RESEARCH AND METHODS}

The research was conducted using qualitative methods through the process of literature study, field research, and interviews with the experts. The approach method that is used was an ethnographic study approach. The study describes and interprets culture, social group, and system point of view. The reference approach was the one that was expressed by Spradely, which investigates a cultural community and environment through primary data collection, observation, and interviews. During the earliest stage, the literature study focused on the history and origins of the Cirebon geography background and its ethnicity. The data collected from literature study was a secondary data. Meanwhile, the field research process includes a direct survey from the Batik Craftsman, Batik Artists, and interviews with the Batik experts. During the data analysis stage, researcher used a method of visual language by Primadi Tabrani [3]. The data obtained through the field research process is primary data. And finally, in the discussion section, this study will see whether the secondary data collected can be proven by primary data.

\section{THE BEGINNING OF THE DEVELOPMENT OF BATIK INDUSTRY IN CIREBON}

In 1799 the power of the VOC (Verenigde OostIndische Compagnie) in Indonesia was taken over by the Dutch kingdom due to the financial crisis in VOC body, then Indonesia became a Dutch colony called the Kingdom of the Dutch East Indies. This occasion has triggered the migration of the Dutch to Indonesia in general to settle in Java [4]. One of the economic strategies of the Dutch East Indies government was to stop imports of textiles from India to improve the unfavourable economic conditions. Eventually, this condition became an opportunity for batik craftsmen in Java, since the nation began to look at Indonesian textiles and caused an increase in the indigenous batik market. Dutch entrepreneurs began to see opportunities for the profitable Batik market and carried out an analysis of the market for Batik produced [5]. It is recorded in a number of literatures written by Europeans, especially Dutch writers, that Javanese batik ornaments are categorized into two commodity characters, which are Batik Istana (Inland Java) and Coastal Batik (North coast of Java).

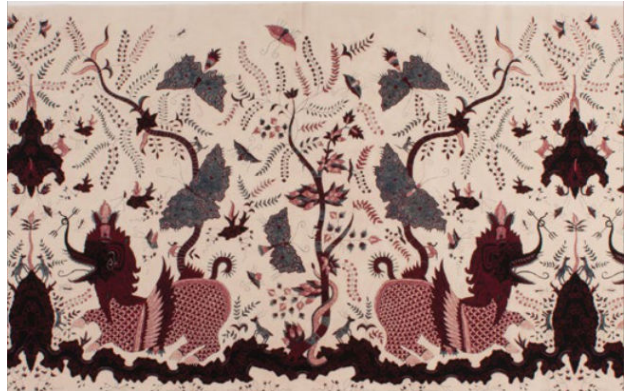

Figure 1. The Batik Istana Ornament of the Kacirebonan Palace; Paksi Nagaliman Batik. (Data Source: Indonesian Batik Foundation Collection)

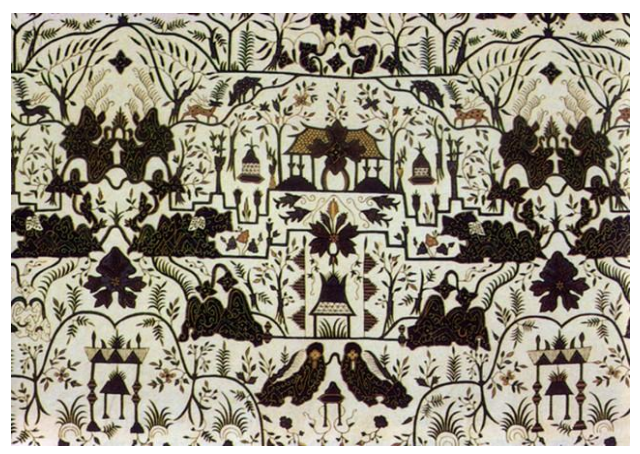

Figure 2. Kauman Batik, Cirebon Palace Classical Batik

(Data Source: Indonesian Batik Foundation Collection)

Batik Istana of Java that was made in the Solo and Yogyakarta Palaces, is also called Vorstenlanden Batik, specifically for the nobility (Figure 2).

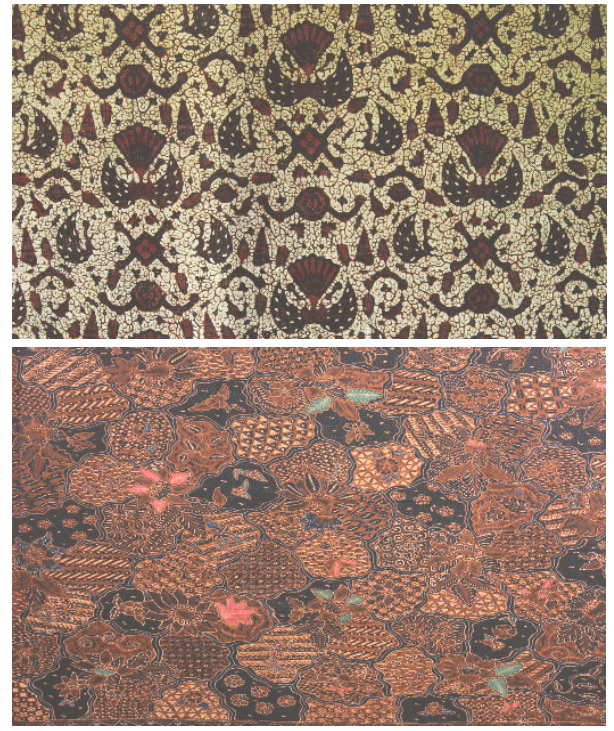

Figure 3. Batik Ornaments of the Yogya Palace and Sekar Jagad Solo, (Data Source: Yogyakarta Batik Graha Collection) 
Batik Istana usually has a special ornament on the standards and symbols that are firmly held in its manufacture, this causes the batik Istana ornament to be somewhat limited in its variants. While the Coastal Batik is a batik ornament that is more widely used by ordinary people, therefore the coastal batik ornament is more dynamic and the variants are very diverse [6]. From the search results, Cirebon has two ornaments, which are Batik Istana and Coastal Batik. This is possible because Cirebon is the centre of the royal government and also as a market port city which makes it a differentiating character for Cirebon batik.

When the colonial period in Indonesia turned into the Kingdom of the Dutch East Indies, textile production was usually imported from India. However, due to the economic crisis during that time, the policy of the Dutch East Indies kingdom has shifted and prioritize more into Indonesian textiles. Seeing these conditions, Dutch textile entrepreneurs saw the potential of Batik and ordered batik ornaments that were tailored to the tastes of Europeans and Cirebon which eventually resulted in new ornaments on batik containing European visual elements [7]. The first recorded productions were folklore ornaments that were popular in Europe (Figure 3) such as stories "Little Red Riding Hood", "Hanzel and Gretel", "Snow White", etc.

The term "Batik Kompeni" was first popularized in the centre of the Cirebon Batik industry and continues to be developed by Traditional Batik artists in Cirebon which later inspired many modern Batik artists. The name of Batik Kompeni was created because the batik ornament depicts a human figure dressed in Dutch soldiers and carrying rifle weapons, where the Dutch soldiers at that time were called Kompeni from "Compagnie", one part of the words Verenigne Ost Indische Compagnie (VOC).

Furthermore, due to the increasing market demand for batik, several indigenous batik artisans collaborated in making batik and started to create a jointly managed business and most of them were Dutch entrepreneurs, generally Indo-Dutch female descendants. The characteristics of the Batik Kompeni ornaments, which later became very diverse, combined traditional Cirebon patterns and ornaments with human figures depicting the lives of Dutch people, especially humans that dressed as Dutch soldiers, fully armed with rifles. Batik ornaments also describes the story about the lives of the Dutch and natives in their daily lives. The main visualization in the Batik Kompeni ornaments tells the social interactions between the Dutch and the natives. [8]

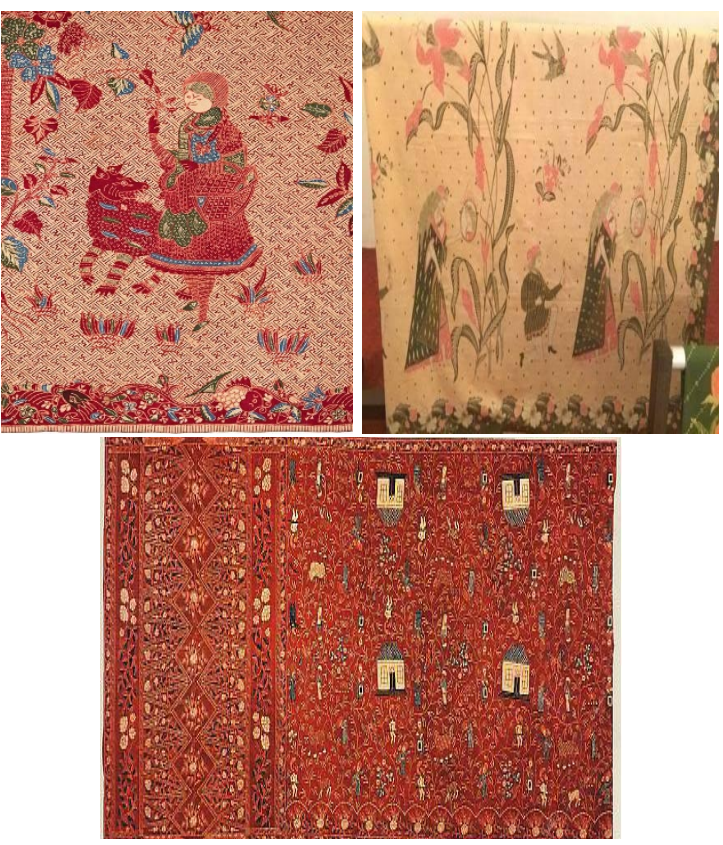

Figure 4. Patterns of European Folklore Batik Ornaments, Red Hat Girl (left), Snow White (right), and Hansel and Gretel (down). (Data Source: Danar Hadi Batik Museum)

For example, in Figure 4, the illustrations and patterns on the ornaments visualize picnic that the Dutch family were having in the park. The drawing of a horse-riding and carriage depicted children playing seesaw, playing swings, and riding horses, and it was all shown through the Batik Kompeni ornament that further describes the story in Cirebon traditional market. One of the characteristics of Batik Kompeni story telling later is the traditional composition in the coloring of the background colour, which consists of ivory and the decoration of only 3 colours. The background colour sometimes only consists of plain color without any isen-isen or nitik. 


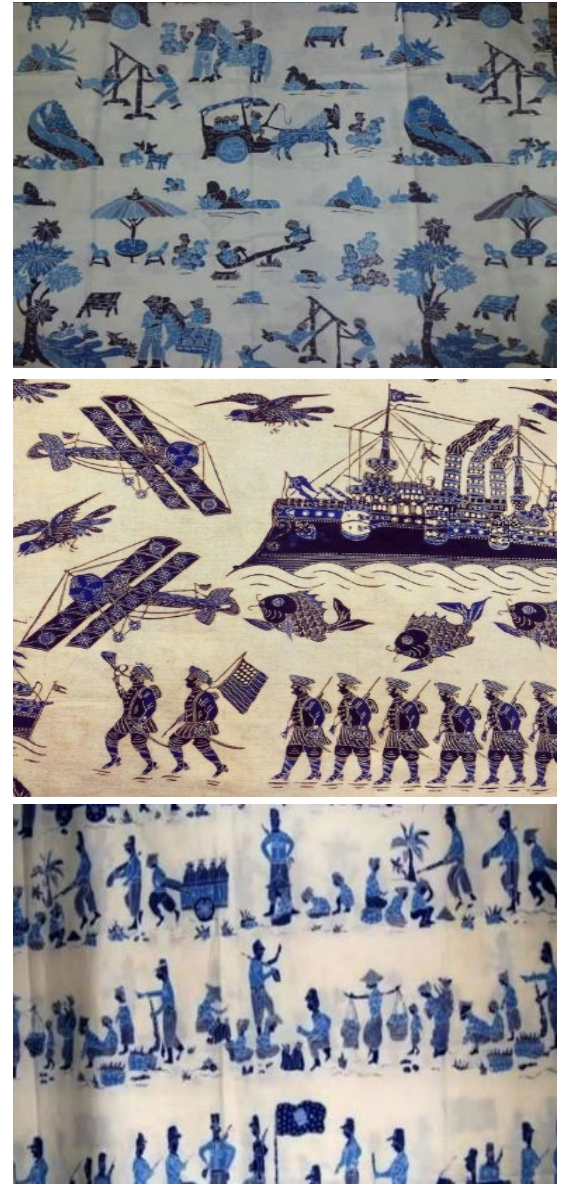

Figure 5. Batik of the Cirebon Kompeni, the ornament of telling a story about a Dutch family having a picnic (up), Military prepare of War (middle), and the ornament of having fun with life in a traditional market (down)

(Source: Researcher Collection Data)

\subsection{The Acculturation Process on the Patterns and Ornaments of the Batik Kompeni in Cirebon (1800-1940)}

After the Dutch kingdom took over Indonesian power from the VOC, which is collapsed due to various socio-economic problems, Indonesia became the territory of the Kingdom of the Dutch East Indies. Another important thing is the economic crisis that results from bankruptcy of the VOC has also caused the transfer of several Indonesian territories, including the island of Java, to the British Empire in 1811-1815. During the British rule under the leadership of the British Governor General Sir Thomas Stamford Raffles, Raffles took a cultural approach to the local population and had given a positive impact, especially on maintaining the diplomatic relations between the Javanese kings and the British Empire. [9]. In 1816, the Java region was then transferred back to the Netherlands, under the leadership of the Governor General of the Dutch East Indies Johannes Graaf van den Bosch. Apparently, he took the initiative to continue Raffles' approach to the Javanese kings. In this period, European culture began to enter intensively and formally it was very possible to be introduced to Javanese society by the Dutch government. The Indigenous Indonesian artists that especially comes from the Cirebon coast, have been accustomed to interacting with various foreign cultures for centuries, including China, India, Arabia and then the West (Europe), especially the Cirebon people on the coastal geographical environment that has the openness and initiative to learn from foreign cultures, in this case drawing techniques and Western aesthetics that applies in the batik ornaments [10].

Furthermore, between the 1800s-1920s, the production of the Batik Kompeni ornaments, apart from Cirebon, has continued to grow, spreading to the coasts of Central Java and East Java, especially in batik centers in the northern coast of Java. During that period, several Indo-Dutch women batik entrepreneurs collaborated with Batik craftsmen to develop their businesses in various cities in the northern coast of Java. Batik centers were then developed and built in Semarang, Ungaran, Pacitan, Surakarta, and Yogyakarta. In 1910, Banyumas and Pekalongan became an important batik industry centers and became centers for the development of the Batik Kompeni in the coastal areas of Central and East Java [11]. The Modernization in the Batik industry has also made the Batik Kompeni's production grow to produce new ornaments and in a more diverse colours. The old patterns are enriched with European-Indonesian-Chinese nuances, and the decorative patterns of flora and fauna that are still more decorative in style appear in the stork ornament from the middle of a clump of aquatic plants, which is called as the Buketan style. [12].

The Javanese decoration style in the bouquet batik pattern called the Mastroman ornament comes from the name of a Dutch entrepreneur named Catharina Carolina van Oosterom, using soga colours to develop a classic batik ornaments such as slopes and Sekar Jagad which are enriched with a touch of 
synthetic colours. This shows that the tradition of batik art is very dynamic and open to technological developments and also the market demand. The progress of the batik industry at that time was so rapid that it was called the peak period of the creation of various Dutch Batik, Batik Kompeni and Buketan Batik. [13].

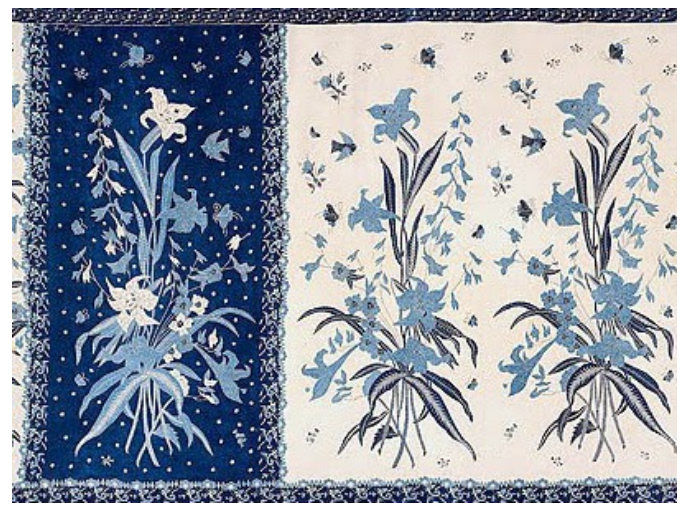

Figure 6. Batik Buketan, Pekalongan, Central Java, Danar Hadi Museum Collection

Subsequently, several indigenous batik artisans collaborated in making batik and started a business managed by Indo-Dutch women entrepreneurs, who were mostly intellectuals. Among them is Catharina Carolina van Oosterom, (the name Oosterom became the name of Batik (mastroman) her typical ornament is Batik Istana with European style. Batik entrepreneurs still sell the Batik Oosterom/Mastroman in the Semarang area until now. During the period of 1840-1940, Pekalongan developed into an important area In the batik industry, it became the batik industry further that developed a variant of Dutch batik. Furthermore, labels and names for the Dutch Batik Kompeni ornaments has also emerged, and among them are taken from the names of Dutch entrepreneurs themselves, such as the pansolen/suilen ornament (from the name Van Zuylen), Frankemon Batik is famous for its colour Batik "green Frankemon" (von the name Franquemont) and Ornament Buketan (the term Bouquiete flower bond) [14].

In addition to Dutch entrepreneurs, there are also breed entrepreneurs from Chinese and Arab batik who also participates in developing the Batik Kompeni variety to meet the increasing market demand. The Indigenous home industries build cooperation with batik entrepreneurs as a work pattern for Batik Kompeni in dealing with large turnover and production as well as a more systematic work system [15]. In 1940-1945, World War 2 occurred and in 1942-1945, and the Japanese occupation occurred. It has caused most of the Dutch in Indonesia to return to the Netherlands or become Japanese prisoners of war. Thus, almost all Dutch batik companies in Java stopped their production. After Indonesia's independence, the Batik industry began to start again and continues to grow until now.

\subsection{Cirebon Batik Development and Modernization}

The Cirebon traditional batik pattern is a combination of various objects made into a decorative style formed from lines and colours that are made manually with the Written Batik Technique (Batik Tulis). The unique appearance of traditional batik generally comes from the basic form of natural objects and then became the creation of interesting and varied decorative style ornaments. It came in the form of flora and fauna, various forms of animals, plants, decorative forms, and various other imaginative forms, except human figurative forms that do not exist, found in old batik patterns [16].

The characteristics of Cirebon batik that are different from other regional batik are as follows [17]:

1. Cirebon classic batik is a decorative ornament of wadasan (rocks) and has the decorative elements of mega mendung (clouds).

2. Cirebon classic batik has a basic colour of ivory as a background, and yellow, dark red, blue, brown, black which are dominant in the main decorative ornament lines.

3. Clean background colours are processed with Cirebon's typical technique of closing (blocking area) using canting wall and bleber, so that the resulting background area is very clean.

4. The lines of ornaments on classic Cirebon batik are very smooth and varied because they use canting with small to large holes according to their designation. 
The development and change of various batik patterns and ornaments in Cirebon is due to cultural interactions throughout centuries. Batik Kompeni Cirebon is one that shows the occurrence of acculturation in the creation and development of Batik ornaments in Cirebon. The typical batik pattern tells the story of the Batik Kompeni that was first discovered in Cirebon, which is the ornament that gives rise to figurative visualization (humans) on the storytelling as a characteristic of the Batik Kompeni [18]. So, it can be said, the development of Batik Bercerita ornaments and figurative styles began in the coastal batik centre area of Cirebon. The new pattern of the Batik Kompeni in Cirebon also contains figurative objects, most likely due to Western modernism, as well as the introduction of techniques on drawing patterns of Batik ornaments by Javanese batik artists [19]. At that time, the batik lover's, Dutch people, and Dutch artists living in Java ordered batik makers in Cirebon to make batik patterns with figurative/illustrative images applied into the batik, which later became known as the Batik Kompeni ornaments and patterns. The new style was produced due to the demand of the Dutch during colonialism around the early 1800s. The influence of Western modernization in aesthetic patterns of Batik ultimately helped enriches style of Indonesian Batik, with the emergence of a new style of Batik Bercerita called Batik Kompeni, a collaboration of Dutch batik artists and entrepreneurs. [20].

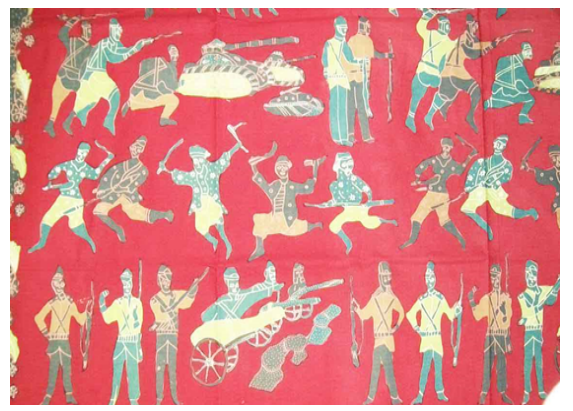

Figure 7. Batik Kompeni (batik cloth patterned on the life of the Dutch colonial period)1800-1940s (Source of Researcher Collection Data)

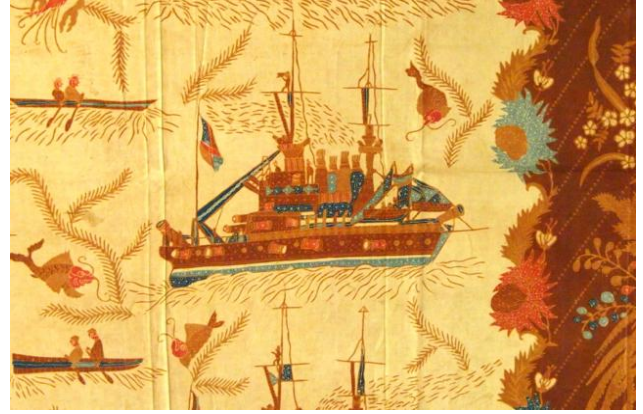

Figure 8. Batik Kompeni, Dutch ship decoration pattern, Pekalongan (Source of Batik Museum Collection)

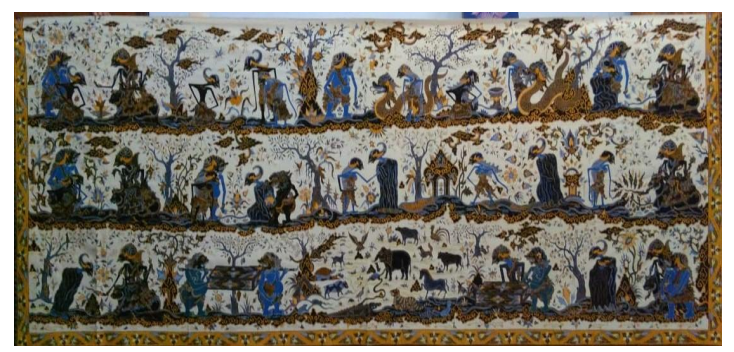

Figure 9. Cirebon Batik Kompeni, Panakawan and Cirebon Panji Stories,

(Source of Researcher Collection Data)

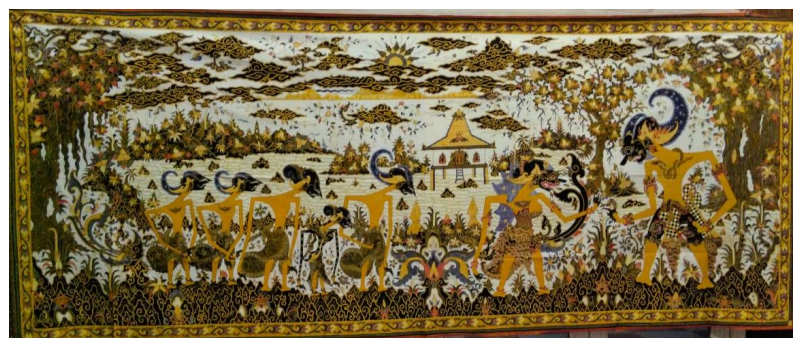

Figure 10. Storytelling Batik with Panakawan and Wayang decorative patterns, Mahabharata scene, (Data Source: Private Collection)

It continued to be developed until the end of colonialism period and post-independence days of Indonesia, including applying the wayang patterns, daily patterns, and street performing arts depicting Indonesian indigenous life [21]. Javanese artists and batik artists especially in Cirebon, developed new batik patterns inspired by pictures/illustrations of ancient Javanese manuscripts, especially illustrations of scenes from the epic story of Mahabaratha [22]. The creativity of Batik artists is on developing Batik Bercerita that was resulted by 
the acculturation of traditional and modern Western aesthetics on creating a new unique patterns of Batik Kompeni ornaments. The process of developing the Batik Kompeni patterns are increasingly developing in the style, the colour, the visual elements and the objects that shows how traditional batik art is very dynamic and open to adaptation, developments and demand of the community.

\subsection{Cultural Acculturation in Cirebon Batik Kompeni}

More artwork of the new batik patterns is created by Batik artists and craftsmen, especially batik that tells stories with everyday themes, folklore and daily events, which are adapted throughout history until nowadays [23]. While many people said that traditional art has not changed, it still adheres to standard rules and regulations over time for generations. In fact, although not as fast as modern art, traditional batik is also gradually developing due to the changing times according to their respective lands. Batik designs, undergo a process of acculturation either made by batik designers or made as the request of the consumers. If the community of a creative group continues to grow, the culture will also develop according to the rhythm of time dynamic. In addition to the Indo-Dutch batik entrepreneurs who own Batik companies, there are also Chinese and Arabian entrepreneurs who produce the Batik Kompeni [24]. At first, the batik business was a local home industry business. Then, Batik craftsmen served orders from the Dutch and Javanese noble as well as for the exports to Europe. The production system of the Batik Industry has evolved from a home industry to become a Batik Industry with a large workplace and more systematic [25].

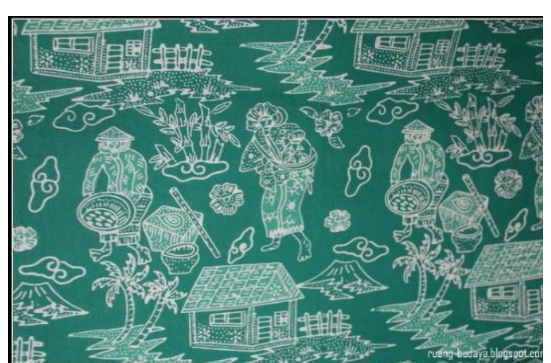

Figure 11. Cirebon Storytelling Batik, Daily Life Batik Ornaments. (Data Source: Researcher Collection)

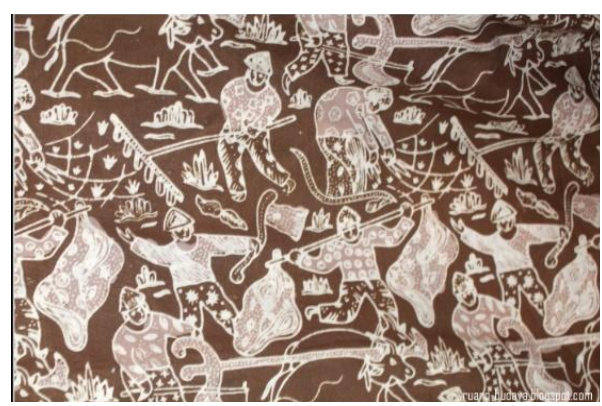

Figure 12. Harvest Period Batik Ornaments, (Data Source: Researcher Collection)

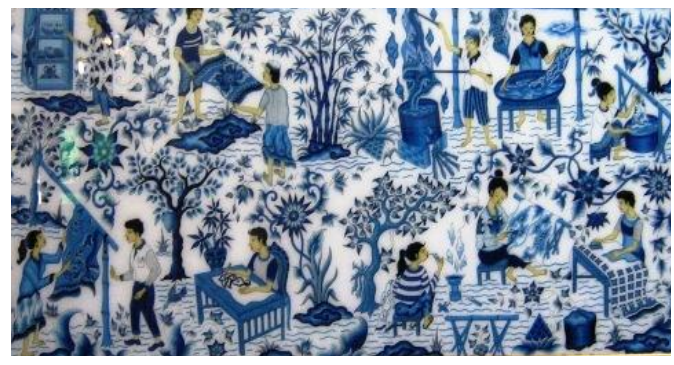

Figure 13. Batik Telling stories with decorative figures and the daily process of batik, Cirebon (Data Source: Researcher Collection)

Images of traditional ornaments and illustrations on the Batik Kompeni in Cirebon shows the creativity of the artists, and several batik acculturation of cultural aesthetic paradigms that comprises of Indonesia, India, China, Middle East and the Europe. The aesthetic concept that produces batik ornaments and patterns causes the emergence of traditional and modern styles into the aesthetic concept which applies to Cirebon's batik ornaments, especially Batik Kompeni [26]. The Batik Kompeni ornament has also become a new unique style, with a paradoxical aesthetic yet harmonious and still has a very strong local content style.

The Visual language were used as a method for analyzing acculturation on the Batik Company ornament, that also refers to the way of depicting an object with certain characteristics, which are generally most visible in the way children draw or

prehistoric drawings. Even though the same object is drawn by people with different cultural backgrounds, it can still be recognized through the visual language they use. Visual language is related to the storytelling aspect of an image. When 
juxtaposed with the use of verbal language or words, Visual Language has images instead of words and grammar instead of grammar. Samples of a number Batik Kompeni ornaments were selected according to the criteria, which showing the existence of a mixture or acculturation in the visual and aesthetic elements of the ornament, using the visual language [27].

Table 1. Analysis of Acculturation of Cirebon Batik Ornaments for the period (1800-2020)

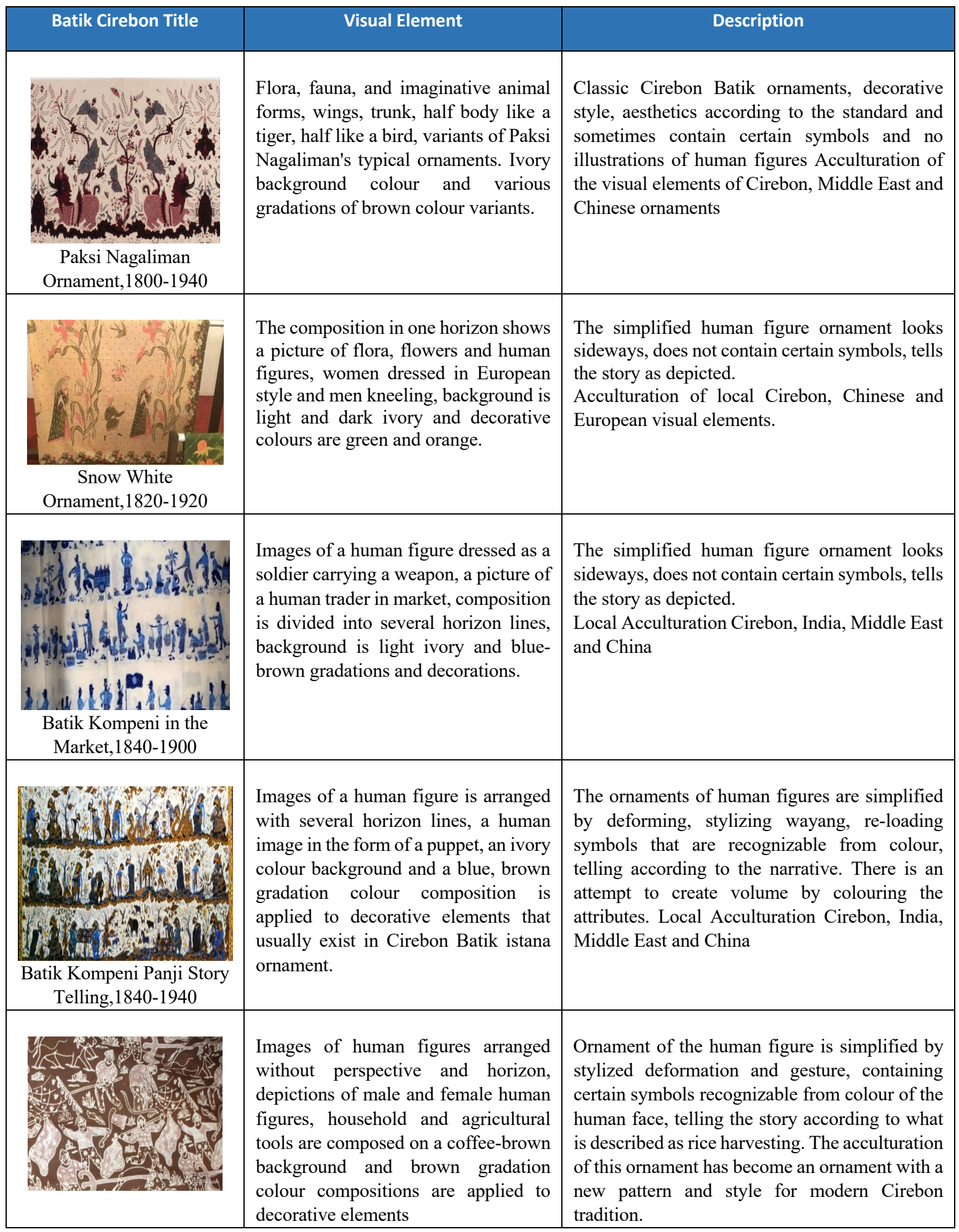




\begin{tabular}{|c|c|c|}
\hline $\begin{array}{l}\text { Batik Kompeni The } \\
\text { Harvest Story, 1900-1920 }\end{array}$ & & \\
\hline 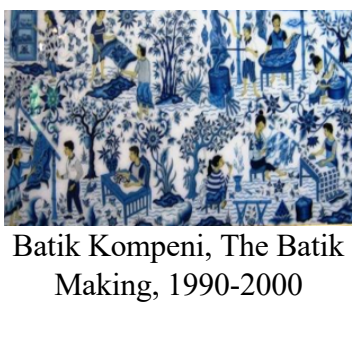 & $\begin{array}{l}\text { Images of human figures are } \\
\text { composed of perspective and horizon, } \\
\text { depictions of male and female human } \\
\text { figures, trees, flora and fauna on } \\
\text { coffee white background and blue and } \\
\text { light-yellow gradation colour } \\
\text { compositions are applied to decorative } \\
\text { elements. }\end{array}$ & $\begin{array}{l}\text { Human figure ornaments with illustrative } \\
\text { approaches to realism, anatomy and gestures, } \\
\text { stories about the process and stages of making } \\
\text { batik. Acculturation of this ornament has } \\
\text { become an ornament with a new pattern and } \\
\text { style in the modern Cirebon tradition. The } \\
\text { acculturation of this ornament has become a new } \\
\text { style of ornament in modern tradition of } \\
\text { Indonesian Batik. }\end{array}$ \\
\hline & $\begin{array}{l}\text { The image of a female human figure } \\
\text { with sleeping gestures without } \\
\text { perspective and horizon, decorative } \\
\text { marine flora and fauna, purple } \\
\text { gradation background and purple, } \\
\text { blue, yellow and red colour } \\
\text { compositions are applied to decorative } \\
\text { elements. }\end{array}$ & $\begin{array}{l}\text { The ornaments of human figures with illustrative } \\
\text { realist styles, anthomies, mythological images } \\
\text { from Roro Kidul, resulted in acculturation of } \\
\text { ornaments with new patterns and styles, modern } \\
\text { traditions developed from the Batik Kompeni } \\
\text { telling stories of Cirebon. The acculturation of } \\
\text { this ornament has become a new style of } \\
\text { ornament in modern tradition of Indonesian } \\
\text { Batik. }\end{array}$ \\
\hline $\begin{array}{l}\text { Batik Kompeni, The Story } \\
\text { of Roro Kidul Mythology } \\
\text {,2020 }\end{array}$ & & \\
\hline
\end{tabular}

These changes and developments has brought the art of batik to a new look with various colors, shapes and purposes. The era of regional autonomy in Indonesia is underway, which is the era where the emergence and rise of traditional arts in every region. All autonomous regions have started to record and observe regional potentials to be appointed, managed and developed as regional assets in the future. Traditional art where Batik Kompeni still exist to welcome the era of the global market. The ethnic batik emerged with new faces and forms as a result of cultural acculturation. The Batik Kompeni's production also underwent changes and quickly developed new or modern batik designs according to the creativity of artists, designers, and market demand.

Cultural acculturation continues to occur in accordance with times, science and technology as well as human intelligence. Globalization happened due to the advancing Internet information technology, which impacts on the spread of culture, that affects the traditions of various nations around the world, by significantly breaking the boundaries of traditional rules. Even so, globalization encourages the advancement of human culture in various aspects. Some concerns about the degradation of cultural identity due to global cultural influences, of course also offers solutions and updates, so that batik art is not only an object of global art, yet it must be able to become an art subject that can determine itself. Being a subject means having the ability to create and innovate works, to be able to contribute to global art. Like the textile products of our ancestors' Batik Kompeni, which have been enriched with visual forms of Cirebon ornaments, it is indeed an example of the creativity of the ancestors on making traditional Batik art that is valuable and timeless for our society.

\section{CONCLUSION}

Acculturation continues to occur along with the times, science, and technology, as well as the evolution of human intelligence. Changes have occurred throughout the ages even before information and technology developed rapidly as it is today. For example, the acculturation process of the Batik Company's ornaments in the period 18001940 , at a slower rate than the current decade. In the global era with internet technology, the rapid disclosure of information causes external cultural 
influences to enter various internal features of our daily lives, directly or in areas that affect the existence of local culture itself. Many contemporary art creators, particularly in the field of batik art, have emerged to be involved in the preservation and introduction of their own culture for the next generation. The creativity and persistence of the designers/batik makers are always looking for and finding something new which always faces challenges to adapt to the future, and continues to look for innovations for developing the artistic creativity in this cultural diversity, so that it finally survived and able to thrive in today's global arena.

\section{ACKNOWLEDGEMENTS}

In accordance with ICON ARCCADE 2021 The $2^{\text {nd }}$ International Conference on Art, Craft, Culture and Design, we would like to take this opportunity to thank for the effort and expertise from the committee. Acknowledgments special honour for the support from the Indonesian Government to Higher Education Excellent Research Grant (20192021).

\section{REFERENCE}

[1] Nuning Damayanti, Narasi Mitos dan

Legenda Indonesia Dalam Ekspresi Batik Tamarin, 2018.

[2] Nuning Damayanti, Narasi Mitos dan Legenda Indonesia Dalam Ekspresi Batik Tamarin, 2018.

[3] Nuning Damayanti, Narasi Mitos dan Legenda Indonesia Dalam Ekspresi Batik Tamarin, 2018 .

[4] P. Tabrani, Bahasa Rupa Dan Kemungkinan Munculnya Senirupa Indonesia Kontemporer Yang Baru, Jurnal Komunikasi Visual WIMBA, vol. 8, no. 1, 2017, pp. 1-12, [Online]. Available:

http://jurnalwimba.com/index.php/wimba/article/vi ew/127/pdf_80.

[5] P. Tabrani, Borobudur Story Relief, a Silent Visual Narration, 2007, pp. 1-14.

[6] P. Tabrani, Borobudur Story Relief , a Silent Visual Narration, 2007, pp. 1-14.

[7] P. Tabrani, Borobudur Story Relief, a Silent Visual Narration, 2007, pp. 1-14.
[8] P. Tabrani, Borobudur Story Relief , a Silent Visual Narration, 2007, pp. 1-14.

[9] R. Mahardika, Y. Fitra A, and E. Dewi K, Pelatihan Lukis Batik dengan Bubur Biji Asam Untuk Guru PAUD, IKRAITH-ABDIMAS Vol, vol. 3, no. 1, 2020, pp. 1-7, [Online]. Available: https://journals.upiyai.ac.id/index.php/IKRAITHABDIMAS/article/view/492/360.

[10] R. Mahardika, Y. Fitra A, and E. Dewi K, Pelatihan Lukis Batik dengan Bubur Biji Asam Untuk Guru PAUD, IKRAITH-ABDIMAS Vol, vol. 3, no. 1, 2020, pp. 1-7, [Online]. Available: https://journals.upiyai.ac.id/index.php/IKRAITHABDIMAS/article/view/492/360

[11] R. Mahardika, Y. Fitra A, and E. Dewi K, Pelatihan Lukis Batik dengan Bubur Biji Asam Untuk Guru PAUD, IKRAITH-ABDIMAS Vol, vol. 3, no. 1, 2020, pp. 1-7, [Online]. Available: https://journals.upiyai.ac.id/index.php/IKRAITH$\underline{\text { ABDIMAS/article/view/492/360 }}$

[12] R. Mahardika, Y. Fitra A, and E. Dewi K, Pelatihan Lukis Batik dengan Bubur Biji Asam Untuk Guru PAUD, IKRAITH-ABDIMAS Vol, vol. 3, no. 1, 2020, pp. 1-7, [Online]. Available: https://journals.upiyai.ac.id/index.php/IKRAITHABDIMAS/article/view/492/360

[13] R. Mahardika, Y. Fitra A, and E. Dewi K, Pelatihan Lukis Batik dengan Bubur Biji Asam Untuk Guru PAUD, IKRAITH-ABDIMAS Vol, vol. 3, no. 1, 2020, pp. 1-7, [Online]. Available: https://journals.upiyai.ac.id/index.php/IKRAITHABDIMAS/article/view/492/360

[14] R. Mahardika, Y. Fitra A, and E. Dewi K, Pelatihan Lukis Batik dengan Bubur Biji Asam Untuk Guru PAUD, IKRAITH-ABDIMAS Vol, vol. 3, no. 1, 2020, pp. 1-7, [Online]. Available: https://journals.upiyai.ac.id/index.php/IKRAITHABDIMAS/article/view/492/360

[15] A. Pandanwangi, A. M. Apin, B. Sukapura Dewi, N. Damayanti, F. Denianshah, and S. Elnissi., Adaptasi Pendampingan Teknik Membatik Media Alternatif Baru di Era New Normal, in Peran Perguruan Tinggi dalam Transformasi, Adaptasi, dan Metamorfosisi Pengabdian pada Masyarakat di Era New Normal, vol. 5, no. 1, pp. 22-26, 2020, 
[Online].Available:

http://repository.unika.ac.id/23450/1/sendimasyogy a20Yekti Tri Menik.pdf.

[16] N. Apriani and A. Pandanwangi, N. Damayanti, Batik gutta tamarind, Likupang, 2020.

[17] N. Apriani and A. Pandanwangi, N. Damayanti, Batik gutta tamarind, Likupang, 2020.

[18] A. Pandanwangi, C. J. Rianingrum, N. Damayanti, and A. Rahmat, The Icon of Local Culture: Downstream of Tamarind Waste as a Superior Motif Barrier in Indonesia, Turkish J. Comput. Math. Educ., vol. 12, no. 13, pp. 15241535, 2021, [Online]. Available: https://turcomat.org/index.php/turkbilmat/article/vi ew/8781.

[19] A. M. Apin et al. A. Pandanwangi, B. S. Dewi, A, and N. Damayanti, Batik Tamarin Empowering Woman in Patimban Subang Indonesia, vol. 07, no. 02, pp. 757-762, 2021, [Online]. Available: http://ejurnal.pps.ung.ac.id/index.php/Aksara\%0A Batik.

[20] B. S. Dewi, A. M. Apin, A. Pandanwangi, and N. Damayanti, Inspirasi Batik Tamarind dari Cerita rakyat,Jurnal Budaya Nusantara, vol. 4, no. April, pp. 269-275, 2021, doi:https://doi.org/10.36456/b.nusantara.vol4.no2.a 4056.

[21] B. S. Dewi, A. M. Apin, A. Pandanwangi, and N. Damayanti, Inspirasi Batik Tamarind dari Cerita rakyat,Jurnal Budaya Nusantara, vol. 4, no. April, pp. 269-275, 2021, doi:https://doi.org/10.36456/b.nusantara.vol4.no2.a 4056.
[22] B. S. Dewi, A. M. Apin, A. Pandanwangi, and N. Damayanti, Inspirasi Batik Tamarind dari Cerita rakyat,Jurnal Budaya Nusantara, vol. 4, no. April, pp. 269-275, 2021, doi:https://doi.org/10.36456/b.nusantara.vol4.no2.a 4056.

[23] B. S. Dewi, A. M. Apin, A. Pandanwangi, and N. Damayanti, Inspirasi Batik Tamarind dari Cerita rakyat,Jurnal Budaya Nusantara, vol. 4, no. April, pp. 269-275, 2021, doi:https://doi.org/10.36456/b.nusantara.vol4.no2.a 4056.

[24] B. S. Dewi, A. M. Apin, A. Pandanwangi, and N. Damayanti, Inspirasi Batik Tamarind dari Cerita rakyat,Jurnal Budaya Nusantara, vol. 4, no. April, pp. 269-275, 2021, doi:https://doi.org/10.36456/b.nusantara.vol4.no2.a 4056.

[25] B. S. Dewi, A. M. Apin, A. Pandanwangi, and N. Damayanti, Inspirasi Batik Tamarind dari Cerita rakyat,Jurnal Budaya Nusantara, vol. 4, no. April, pp. 269-275, 2021, doi:https://doi.org/10.36456/b.nusantara.vol4.no2.a 4056.

[26] B. S. Dewi, A. M. Apin, A. Pandanwangi, and N. Damayanti, Inspirasi Batik Tamarind dari Cerita rakyat,Jurnal Budaya Nusantara, vol. 4, no. April, pp. 269-275, 2021, doi:https://doi.org/10.36456/b.nusantara.vol4.no2.a 4056.

[27] B. S. Dewi, A. M. Apin, A. Pandanwangi, and N. Damayanti, Inspirasi Batik Tamarind dari Cerita rakyat,Jurnal Budaya Nusantara, vol. 4, no. April, pp. 269-275, 2021, doi:https://doi.org/10.36456/b.nusantara.vol4.no2.a 4056. 